\title{
Further studies on the composition of human femoral head cartilage
}

\author{
A. MAROUDAS, ${ }^{1}$ M. T. BAYLISS ${ }^{2}$ AND M. F. VENN ${ }^{1}$
}

From the ${ }^{1}$ Bone and Joint Research Unit, London Hospital Medical College, London E1 2AD, and the ${ }^{2}$ Institute of Orthopaedics, Royal National Orthopaedic Hospital, Stanmore, Middlesex

SUMMARY This report continues our previous studies on the composition and swelling of articular cartilage. When the protein part of the proteoglycan moiety has been taken into consideration, there is no longer a large fraction of the tissue which is not accounted for. In fact, the collagen, proteoglycans, and free electrolyte represent over $92 \%$ of the dry weight of adult femoral head cartilage, the remainder consisting most probably of other glycoproteins. Once the composition of cartilage had been well defined, it was possible to calculate the overall wet volume of tissue per unit weight of collagen for both normal and osteoarthritic cartilage. This is an important parameter, as it constitutes a direct measure of the extensibility of the collagen network. By determining the fixed charge density profile close to the articular surface, we have also been able to estimate the swelling pressure due to the proteoglycans in this region of the tissue, and to show that there is a gentle grading of osmotic stresses.

The variation in the composition of human articular cartilage with distance from the articular surface has been studied in normal femoral condyles ${ }^{1}$ and in normal and osteoarthritic femoral heads from patients in the age range $50-80 .^{23}$ Venn $^{4}$ extended the latter studies to include other age groups and was able to examine how the composition of normal, visually intact cartilage changed with age.

One of the shortcomings of the above studies was that a proportion of the dry weight had not been accounted for, the missing fraction amounting in the older age groups to as much as $30 \%$. In the meantime it became clear ${ }^{5}$ that in human articular cartilage the proteoglycans contained far more protein than was the case in proteoglycans extracted from other cartilages. It was thus most likely that the proteoglycan protein would account for a considerable fraction of the 'missing component'.

One of the aims of the present work was to combine the published data of Venn ${ }^{4}$ with those of Bayliss and $\mathrm{Ali},{ }^{5}$ supplementing them where possible with new experimental results, in order to determine in absolute quantities (a) the amount of protein associated with the proteoglycans which is present in cartilage from different age groups, and (b)

Accepted for publication 10 October 1979

Correspondence to Dr Maroudas, Bone and Joint Research Unit, London Hospital Medical College, 25-29 Ashfield Street, London E1 2AD. to estimate the noncollagenous protein which exists? in cartilage as a separate entity from the proteoglycans. Once this was done we would be in a position to assess whether the mass balance was complete.

Furthermore, once the composition of the tissue had been fully determined in relation to both depth from the articular surface and age, we proposed to calculate the wet volume of cartilage per unit weight of collagen as a function of these parameters. The 'wet volume' of cartilage depends on the balance between the swelling pressure gradients due to the proteoglycans and the tensile stresses exerted by the collagen network ${ }^{6} 7$ and is thus a valuable index of the integrity of the latter.

It has been suggested ${ }^{8}{ }^{9}$ that the gradual increase in the glycosaminoglycan (GAG) content from the articular surface to the middle zone serves a very important function of creating an even gradient of swelling pressure in the tissue. Indeed, if the high concentration of GAG which cartilage must have in order to resist satisfactorily the large compressive stresses to which joints are subjected during life were uniform throughout the cartilage thickness, right up to the interface with synovial fluid, there would be a steep osmotic pressure gradient across this interface. This in turn would mean a very high local tension in the collagen fibre network, which would make it susceptible to fatigue failure. In 
reality the GAG concentration at the surface is at its lowest, rising gradually to a broad peak in the middle zone.

Unfortunately in the past it has been possible to form only rough estimates of the swelling pressure gradients in cartilage,${ }^{8}$ since neither had the swelling pressure of cartilage proteoglycans been determined, within the physiological range of concentrations, nor had the variation of fixed charge density with distance been accurately measured in the surface zone. Since, recently, data have become available on the osmotic pressure of isolated proteoglycans at the concentrations present in cartilage, ${ }^{10}$ all we needed in order to form a better estimate of the swelling pressure gradients in femoral head cartilage was to determine the fixed charge density profiles in the surface zone. The final aim of the present work was thus to carry out such measurements and to examine the relationship between the calculated osmotic pressure gradients and the hydrated tissue volume.

\section{Materials and methods}

\section{DETERMINATION OF CHEMICAL COMPOSITION}

Human femoral heads with an age range of 3 to 86 years were obtained at post-mortem and stored at $-20^{\circ} \mathrm{C}$ until use. Full depth plugs of cartilage $(1 \mathrm{~cm}$ diameter) were excised from the superior region of the femoral head. Specimens which showed any surface defect or which stained with Indian ink were rejected. To give an indication of the changes in chemical composition with depth, one chunk from each pair was sliced into $200 \mu \mathrm{m}$ slices parallel to the articular surfaces using a freezing microtome. The other specimen was analysed intact. Mean values were obtained for the variation of cartilage composition with depth for 4 age ranges: 3 to 20 ; 20 to $40 ; 40$ to 60 ; and 60 to 90 years.

For the determination of fixed charge density profiles near the articular surface full depth cartilage chunks were sliced into $50-100 \mu \mathrm{m}$ slices.

\section{PROTEOGLYCAN EXTRACTION}

The extraction of proteoglycans and the determination of protein to uronate ratios in the extracts was carried out on specimens similar to those used for chemical analysis (Venn ${ }^{4}$ and unpublished). It should be stressed, however, that they were not obtained from the same individuals as the latter but from independent samples; nevertheless, the present results show satisfactory agreement with those obtained by chemical analysis (see under 'Results'). For the ion exchange chromatography of fraction $A_{2}$ pooled specimens of normal cartilage from the 40-60 age group were used.
CHEMICAL ANALYSIS OF CARTILAGE

The wet weight of each specimen was determined after soaking in $0.15 \mathrm{M} \mathrm{NaCl}$. The dry weight was determined by drying to constant weight at $67^{\circ} \mathrm{C}$.

Cartilage samples were digested in papain solution $\left(1 \mathrm{ml} / 20 \mathrm{mg}\right.$ dry weight) overnight at $67^{\circ} \mathrm{C} .1^{11}$ The digests were diluted and duplicate samples taken for chemical analysis. The uronic acid content was estimated by an automated version ${ }^{12}$ of the Bitter and Muir procedure. ${ }^{13}$ Hexosamine content was determined by the Elson and Morgan reaction. ${ }^{14}$ Hydroxyproline was determined by the Stegemann method $^{15}$ as modified for automated analysis by Grant. ${ }^{16}$

Collagen content was calculated by multiplying the hydroxyproline results by a factor of $7 \cdot 6$. Chondroitin sulphate content was estimated from the uronic acid content $(\mathrm{mmol} / \mathrm{g})$ and expressed as a percentage of the wet or dry weight by multiplying by a factor of 513 (the molecular weight of the disaccharide). Keratan sulphate was estimated by subtracting the uronic from the hexosamine content $(\mathrm{mmol} / \mathrm{g})$ and the total calculated by multiplying by 464 .

\section{FIXED CHARGE DENSITY DETERMINATIONS}

Fixed charge density (FCD) profiles were obtained by the tracer cation method, as previously described. ${ }^{217}$ It should be noted that the equilibration in ${ }^{22} \mathrm{Na}$ labelled $0 \cdot 015 \mathrm{NaCl}$ solution was carried out on full-depth cartilage chunks, which were only subsequently cut into $50-100 \mu \mathrm{m}$ slices, the radioactivity of each slice being then individually determined. By using this sequence of operations one ensures that any PG losses, which are liable to occur during the soaking of fine slices of cartilage in aqueous solution, will not effect the uptake of ${ }^{22} \mathrm{Na}$ and hence the FCD measurement. Equilibration in radioactive tracer prior to slicing also has the obvious advantage of rapidity over the alternative method of first slicing the cartilage and then equilibrating each slice separately.

Because it was our aim to obtain as accurate a profile of FCD versus depth as possible the thickness of each slice was individually checked with a micrometer. The wet weight of the slices was obtained after they had been soaked in $0 \cdot 15 \mathrm{M} \mathrm{NaCl}$ solution in order to desorb the radioactive tracer. The slices were finally dried in an oven at $67^{\circ} \mathrm{C}$ to constant weight and weighed again.

Since osmotic pressure depends on the molal concentration of GAG, it was essential to know as closely as possible the water content of each slice, as present before excision of the cartilage from the joint. We have shown previously ${ }^{2}$ that normal cartilage increases very little in weight ( $2 \%$ or less) upon excision 
and immersion in physiological saline, provided all cutting operations are carried out at 100\% humidity. Hence the wet weights of slices after resoaking in $0.15 \mathrm{M} \mathrm{NaCl}$ are less than $2 \%$ higher than they would have been in the intact joint and can be safely used in our osmotic pressure estimates.

\section{EXTRACTION AND PURIFICATION OF}

\section{PROTEOGLYCANS AND THEIR ANALYSIS}

Cartilage (either in the form of full-depth chunks or of pooled $200 \mu \mathrm{m}$ slices, obtained from the same level) was sliced with a scalpel under sterile conditions on a cooled Petri dish and then powdered in a Spex freezer mill, as described by Bayliss and Ali. $^{5}$

The powdered sample was extracted for $24 \mathrm{~h}$ at $4^{\circ} \mathrm{C}$ with $4 \mathrm{M}$ guanidinium chloride, $\mathrm{pH} 7.0(10 \mathrm{ml} / \mathrm{g}$ tissue). The residues were removed by centrifugation or filtration through sterile gauze and washed with a small volume of cold $4 \mathrm{M}$ guanidine chloride, $\mathrm{pH}$ 7.0. Extracts and washings were combined and dialysed against 9 vols $0 \cdot 1 \mathrm{M}$ sodium phosphate buffer, $\mathrm{pH} 7 \cdot 0$. The dialysed extracts were then adjusted to a density of $1.50 \mathrm{~g} / \mathrm{ml}$ with solid $\mathrm{CsC} 1$ and centrifuged for $48 \mathrm{~h}$ at $35000 \mathrm{rpm}(95000 \mathrm{~g}$ av.) at $10^{\circ} \mathrm{C}$ on an MSE Superspeed 50 centrifuge in an $8 \times 25 \mathrm{ml}$ angle rotor. Gradients were separated

Table 1 Protein to uronic acid ratios in the proteoglycans extracted from full-depth cartilage

\begin{tabular}{lll}
\hline $\begin{array}{l}\text { No. of } \\
\text { individuals }\end{array}$ & Age group & $\begin{array}{l}\text { Protein to uronate ratio } \\
\text { in GuCl extract }\end{array}$ \\
\hline 4 & $10-19$ & $1 \cdot 53 \pm 0 \cdot 066$ \\
4 & $20-39$ & $2 \cdot 38 \pm 0 \cdot 32$ \\
8 & $40-59$ & $4 \cdot 25 \pm 0 \cdot 18$ \\
11 & $60-90$ & $4 \cdot 9 \pm 0 \cdot 50$ \\
\hline
\end{tabular}

Details of ages in each group:

Age group Ages

10-19 13,13,14, 19.

20-39 20, 21, 34, 34 .

$40-59 \quad 40,47,48,52,52,53,55,58$.

$60-90 \quad 62,68,70,75,78,78,80,82$. by upward displacement into a high density fraction $\left(A_{1}=5 \mathrm{ml}\right)$ and a low density fraction $\left(A_{2}=13 \mathrm{ml}\right) .^{5}$ Fractions $A_{1}$ and $A_{2}$ were then dialysed against $0 \cdot 1 \mathrm{M}$ sodium phosphate buffer, $\mathrm{pH} 7 \cdot 0$, containing $0 \cdot 1 \mathrm{M} \mathrm{NaCl}$.

After extraction the cartilage residues were thoroughly washed with sterile $0.9 \% \mathrm{NaCl}$ and then digested with papain. Uronic acid and total protein contents were determined in the $A_{1}$ and $A_{2}$ fractions by the same methods as described previously. ${ }^{5}$ The residue digest was also analysed for uronic acid.

\section{ION EXCHANGE CHROMATOGRAPHY ON} FRACTION $A_{2}$

Fraction $\mathrm{A}_{2}$ from the associative equilibrium density gradient was exhaustively dialysed against $0.05 \mathrm{M}$ Tris $\mathrm{HCl}$ buffer, $\mathrm{pH} \mathrm{7 \cdot 2}$. A sample $(2 \mathrm{ml})$ of the dialysed fraction was applied to a column $(0.9 \mathrm{~cm} \times 15 \mathrm{~cm})$ packed with DEAE-cellulose (DE32) and equilibrated with $0.05 \mathrm{M}$ Tris $\mathrm{HC1}, \mathrm{pH}$ $7 \cdot 2$. The column was washed with the equilibrating buffer and the effluent monitored at $280 \mathrm{~nm}$. When free of all unbound material $(30 \mathrm{ml})$, the column was eluted with a gradient of sodium chloride (0-2 M)

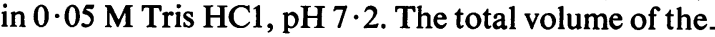
gradient was $200 \mathrm{ml}$. Fractions $(2 \mathrm{ml})$ were collected and monitored for protein at $280 \mathrm{~nm}$ and for uronic acid by the method of Bitter and Muir. ${ }^{13}$ The proportion of total protein attributable to proteoglycans in fraction $A_{2}$ was estimated by cutting and weighing the $280 \mathrm{~nm}$ trace.

\section{Results \\ COMPOSITION OF NORMAL CARTILAGE}

AS A FUNCTION OF AGE

Table 1 shows the ratios of proteoglycan (PG) protein to uronic acid content determined in the guanidinium chloride extracts of full depth cartilage representative of different age groups.

Table 2 Chemical composition of normal femoral head cartilage for different age groups (all percentages are based on wet tissue weight)

\begin{tabular}{|c|c|c|c|c|c|c|c|c|c|c|c|}
\hline $\begin{array}{l}\text { Age } \\
\text { group }\end{array}$ & $\begin{array}{l}\text { No. of } \\
\text { speci- } \\
\text { mens }\end{array}$ & $\begin{array}{l}\text { Uronic } \\
\text { acid } \\
\text { content } \\
(\%)\end{array}$ & $\begin{array}{c}C S \\
(\%)\end{array}$ & $\begin{array}{c}K S \\
\%\end{array}$ & $\begin{array}{c}\text { Total } \\
\text { GAG } \\
\%\end{array}$ & $\begin{array}{l}\text { Protein/ } \\
\text { uronic } \\
\text { ratio }\end{array}$ & $\begin{array}{l}P G \\
\text { protein } \\
\%\end{array}$ & $\begin{array}{l}\text { Collagen } \\
\%\end{array}$ & $\begin{array}{l}\text { Water } \\
\%\end{array}$ & $\begin{array}{l}\text { Sum of } P G, \\
\text { collagen, } \\
\text { and water } \\
\%\end{array}$ & $\begin{array}{l}\text { Total wet } \\
\text { volume of } \\
\text { tissue per unit } \\
\text { wt of collagen }\end{array}$ \\
\hline $\begin{array}{r}3-19 \\
20-39 \\
40-59 \\
60-90\end{array}$ & $\begin{array}{l}7 \\
7 \\
9 \\
5\end{array}$ & $\begin{array}{l}0.98 \\
0.99 \\
1.00 \\
0.92\end{array}$ & $\begin{array}{l}2 \cdot 86 \pm 0 \cdot 10 \\
2 \cdot 89 \pm 0 \cdot 10 \\
2 \cdot 91 \pm 0 \cdot 081 \\
2 \cdot 70 \pm 0.094\end{array}$ & $\begin{array}{c}0.83 \pm 0.095 \\
1.65 \pm 0.21 \\
2 \cdot 20 \pm 0.18 \\
3.03 \pm 0.04\end{array}$ & $\begin{array}{l}3 \cdot 69 \\
4 \cdot 55 \\
5 \cdot 11 \\
5 \cdot 73\end{array}$ & $\begin{array}{l}1 \cdot 53^{*} \\
2 \cdot 40 \\
4 \cdot 25 \\
4 \cdot 9\end{array}$ & $\begin{array}{l}1 \cdot 51 \\
2 \cdot 38 \\
4 \cdot 25 \\
4 \cdot 50\end{array}$ & $\begin{array}{l}18 \cdot 5 \pm 1 \cdot 4 \\
18 \cdot 3 \pm 1 \cdot 7 \\
17 \cdot 3 \pm 1 \cdot 2 \\
16 \cdot 9 \pm 1 \cdot 5\end{array}$ & $\begin{array}{l}75 \cdot 0 \pm 1 \cdot 1 \\
73 \cdot 2 \pm 0 \cdot 52 \\
71 \cdot 2 \pm 0 \cdot 51 \\
69 \cdot 6 \pm 0 \cdot 62\end{array}$ & $\begin{array}{l}98 \cdot 7 \\
98 \cdot 45 \\
97 \cdot 85 \\
96 \cdot 5\end{array}$ & $\begin{array}{l}4.96 \pm 0.041 \\
5.02 \pm 0.050 \\
5.32 \pm 0.052 \\
5.34 \pm 0.060\end{array}$ \\
\hline
\end{tabular}

Details of ages in each age group:

Age group Ages

3-19 $3,5,11,11,14,15,17$ years.

20-39 $23,26,32,32,36,38,39$ years.

$40-59 \quad 41,47,52,53,54,57,58,59,59$ years.

$60-90 \quad 62,69,72,76,86$ years. 
These ratios were calculated by adding to the protein of the $A_{1}$ fraction $25 \%$ of the protein content of the $\mathrm{A}_{2}$ fraction. This figure of $25 \%$ is based on the amount of protein which we found associated with the uronic acid when we applied ion exchange chromotography to fraction $\mathrm{A}_{2}$ from 6 pooled specimens of cartilage in the 40-60 age group. It should be stressed that this figure is based on a mean result for one age group and can thus only be treated as an estimate for the other age groups. However, since the total protein content in the $A_{2}$ fraction of the younger specimens is very lowapproximately $1 \%$ of wet tissue weight (calculated from the results published by Bayliss and $\mathrm{Ali}^{5}$ even a $100 \%$ error in our estimate of the PG protein present in this fraction would lead to no more than a $20 \%$ error in the estimate of the total PG protein.

A further assumption used in our calculations was that the ratio of protein to uronic acid was the same in the proteoglycan molecules remaining in the residue as in those extracted. This assumption is made on the basis of the fact that we find similar total hexosamine to uronic acid ratios in the $\mathrm{GuCl}$ extract as in the residue and as in the digest of the unextracted tissue (Bayliss, Venn, and Maroudas, in preparation). Since the protein to uronic ratio usually parallels the hexosamine to uronic acid ratio, we consider there is a high probability that the former too is the same in the residue as in the extract.

Furthermore, since in our hands the overall extraction efficiency of uronic acid is about $75 \%$, the error introduced in the final estimate of the PG protein content cannot be very large. Even if the uronic acid in the residue were associated with no protein (a very unlikely supposition in view of what has been said above), the total PG protein content as quoted in our tables would be decreased by only $25 \%$.

The values of the protein to uronic acid ratios given in Table 1 were used to calculate the total concentration of proteoglycan protein in cartilage.

Although it must be borne in mind that the protein to uronate ratios on one hand (Tables 1 and 3 ) and the remaining analytical data on the other (Tables 2 and 4) were obtained on specimens belonging to different sets of individuals, the justification for combining the 2 sets of data is as follows.

The uronic acid contents quoted in Tables 2 and 4 and obtained by Venn ${ }^{4}$ closely correspond to those obtained from the results of uronic acid analyses carried out on the cartilage extracts and the residues of the specimens which were used for the determination of the protein to uronic acid ratios (Bayliss, unpublished results). The total hexosamine

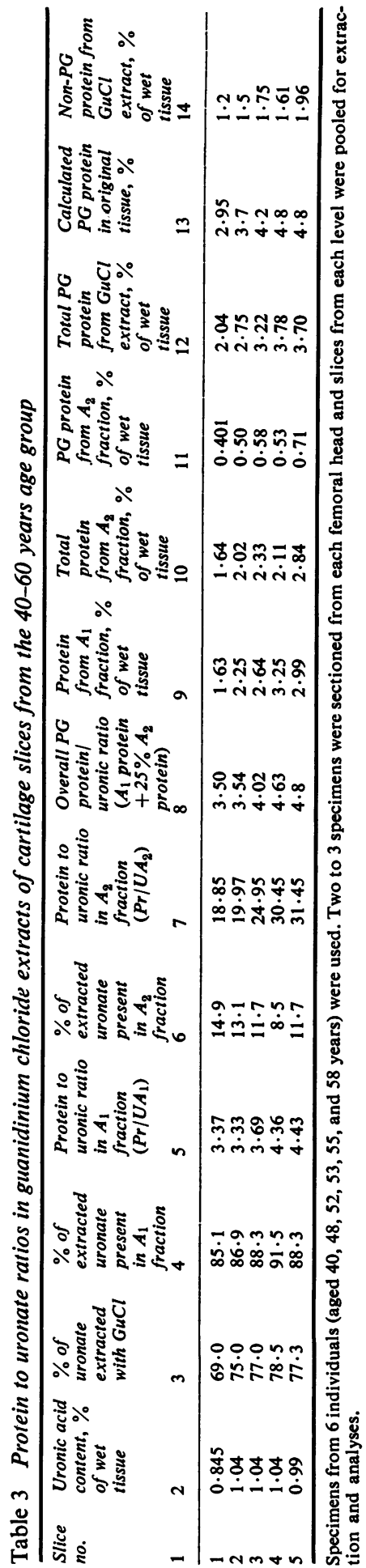


Table 4 Variation in chemical composition with depth in the 40-60 age group (all percentages are based on wet tissue weight)

\begin{tabular}{|c|c|c|c|c|c|c|c|c|c|c|c|}
\hline $\begin{array}{l}\text { Slice } \\
\text { no. }\end{array}$ & $\begin{array}{l}\text { Uronic } \\
\text { acid } \\
\text { content } \\
\%\end{array}$ & $\begin{array}{l}C S \\
\%\end{array}$ & $\begin{array}{l}K S \\
\%\end{array}$ & $\begin{array}{l}\text { Total } \\
\text { GAG } \\
\%\end{array}$ & $\begin{array}{l}\text { PG protein/ } \\
\text { uronic ratio } \\
\text { in } \mathrm{GuCl} \\
\text { extract }\end{array}$ & $\begin{array}{l}P G \text { protein } \\
\%\end{array}$ & $\begin{array}{l}\text { Total } P G \\
(G A G+P G \\
\text { protein) }\end{array}$ & $\begin{array}{l}\text { Collagen } \\
\%\end{array}$ & $\begin{array}{l}\text { Water } \\
\%\end{array}$ & $\begin{array}{l}\text { Sum of all } \\
\text { components } \\
\%\end{array}$ & $\begin{array}{l}\text { Total wet } \\
\text { volume per } \\
\text { unit wt. of } \\
\text { collagen }\end{array}$ \\
\hline $\begin{array}{l}1 \\
2 \\
3 \\
4 \\
5 \\
6\end{array}$ & $\begin{array}{l}0.845 \\
1.04 \\
1.04 \\
1.04 \\
0.99 \\
1.00\end{array}$ & $\begin{array}{l}2.45 \\
3.00 \\
3.00 \\
3.00 \\
2.86 \\
2.90\end{array}$ & $\begin{array}{l}1 \cdot 02 \\
1 \cdot 75 \\
2 \cdot 58 \\
2 \cdot 71 \\
3 \cdot 13 \\
3 \cdot 04\end{array}$ & $\begin{array}{l}3 \cdot 47 \\
4 \cdot 75 \\
5 \cdot 58 \\
5 \cdot 71 \\
5 \cdot 99 \\
5 \cdot 94\end{array}$ & $\begin{array}{l}3 \cdot 50 \\
3 \cdot 5 \\
4 \cdot 02 \\
4 \cdot 63 \\
4 \cdot 8\end{array}$ & $\begin{array}{l}2 \cdot 95 \\
3 \cdot 7 \\
4 \cdot 2 \\
4 \cdot 85 \\
5 \cdot 0\end{array}$ & $\begin{array}{r}6.42 \\
8.45 \\
9.78 \\
10.56 \\
11 \cdot 0\end{array}$ & $\begin{array}{l}20 \cdot 0 \\
18 \cdot 0 \\
15 \cdot 1 \\
15 \cdot 0 \\
15 \cdot 4 \\
17 \cdot 9\end{array}$ & $\begin{array}{l}73 \cdot 0 \\
73 \cdot 0 \\
73 \cdot 0 \\
71 \cdot 5 \\
71 \cdot 0 \\
68 \cdot 0\end{array}$ & $\begin{array}{l}99 \cdot 4 \\
99 \cdot 5 \\
98 \cdot 0 \\
97 \cdot 1 \\
97 \cdot 4 \\
96 \cdot 9\end{array}$ & $\begin{array}{l}4 \cdot 6 \\
5 \cdot 1 \\
6 \cdot 1 \\
6 \cdot 2 \\
5 \cdot 9 \\
5 \cdot 0\end{array}$ \\
\hline
\end{tabular}

The above slices were obtained from cartilage taken from the same individuals as the full-depth chunks for which the results are given in Table 2 . Usually at least 2 full depth blocks of cartilage were sectioned per individual.

to uronic acid ratios are also very close in both sets of data (Bayliss, unpublished results). This consistency of the material with 2 independent methods thus justifies the validity of combining the 2 sets of results.

The composition of normal femoral head cartilage in different age groups, as well as the volume of the tissue per unit weight of collagen, are given in Table 2. As has previously been reported, the chondroitin sulphate (CS) content remains constant whilst the keratan sulphate (KS) content steadily increases with increasing age; there is a slight decrease in the collagen concentration as well as in the water content. Also in accordance with previous observations ${ }^{5}$ there is a rise in the protein content of the proteoglycans, parallelling the increase in the proportion of KS to CS.

It was assumed in our calculations, that the uronic acid present in the form of hyaluronate was negligible in relation to that existing as chondroitin sulphate and all the uronic acid was taken as representing CS. In fact this is not so, since Sweet et al. ${ }^{18}$ have shown that as much as $16 \%$ of the total uronic acid in adult human articular cartilage exists in the form of hyaluronic acid. Our simplification, however, does not alter the mass balance, since the molecular weights of hyaluronic acid and CS differ by only about $20 \%$ (this would mean a $2 \%$ or so difference in total GAG content if the relevant correction were made in Tables 2 and 4 , which is well within our standard deviation).

It should be noted that once the protein content of the PG has been included in the percentage composition, the fraction of the tissue not accounted for is small $(1-3 \%$ on a wet weight basis or $4-10 \%$ on dry weight basis). The electrolyte content (over and above the sodium which is stiochoimetrically equivalent to the negatively charged groups and was included as part of CS and KS) is around $0.5 \%$ by wet weight $(1.5 \%$ by dry weight). The remainder of the tissue, varying from less than $1 \%$ by wet weight for the 3-20 years age group to around 3\% for the $60-90$ group, consists most probably of noncollagenous, nonproteoglycan proteins. In fact, if one calculates the contents of nonproteoglycan protein from the figures for total protein in the $\mathrm{A}_{2}$ fraction given by Bayliss and $\mathrm{Ali}^{5}$ for cartilage specimens from patients of different ages, the values one obtains range from $1 \%$ to $2 \cdot 2 \%$ and thus tally very well with those deduced from the mass balance in Table 2.

Once the composition of cartilage is known, it becomes possible to calculate the volume of the tissue per unit weight of collagen. We will denote this parameter by $\mathrm{V}$, which is calculated from the formula:

$\frac{\mathrm{V}=}{\% \text { GAG } \times 0.52+(\% \text { collagen }+\% \text { non-collogenous protein }) \times 0.74}$.

We have assumed the specific volume of the GAGs to be 0.52 and that of the proteins $0 \cdot 74 .^{19-21}$ The results of the calculation are shown in the last column of Table 2 . It should be noted the standard deviations are large, chiefly because of the errors involved in the collagen determinations. However, in spite of this our results seem to indicate a trend to a slight increase in the tissue volume per unit weight of collagen from the young to the over- 40 age group (see Fig. 4). This is chiefly due to a slight decrease in the collagen content (Table 2).

COMPOSITION OF NORMAL CARTILAGE AS A FUNCTION OF DEPTH FROM THE SURFACE FOR THE 40-60 AGE GROUP

Table 3 shows the protein to uronic acid ratios present in the $A_{1}$ and $A_{2}$ fractions of the $\mathrm{GuCl}$ extracts of tissue slices in the 40-60 age group, together with the uronic acid content of the slices as well as the percentage extraction and the relative amounts of uronic acid in the 2 fractions. These data enabled us to calculate the concentration of total extractable protein in the cartilage slices at different depths from the surface (sum of values in columns 9 and 10, Table 3) and to estimate the amount 
of protein in the tissue associated with the proteoglycan moiety (column 13, Table 3). For the estimate of the latter, the same assumptions were made as above. The difference between the values in columns 10 and 11 gave the concentration of extractable, nonproteoglycan protein in the tissue slices.

It can be seen from Table 3 that both the proteoglycan protein and the nonproteoglycan protein increase in concentration form the surface to the deep zone, although it is clear that even in the deep zone the nonproteoglycan protein constitutes only a small proportion of the whole tissue.

The concentrations of proteoglycan protein

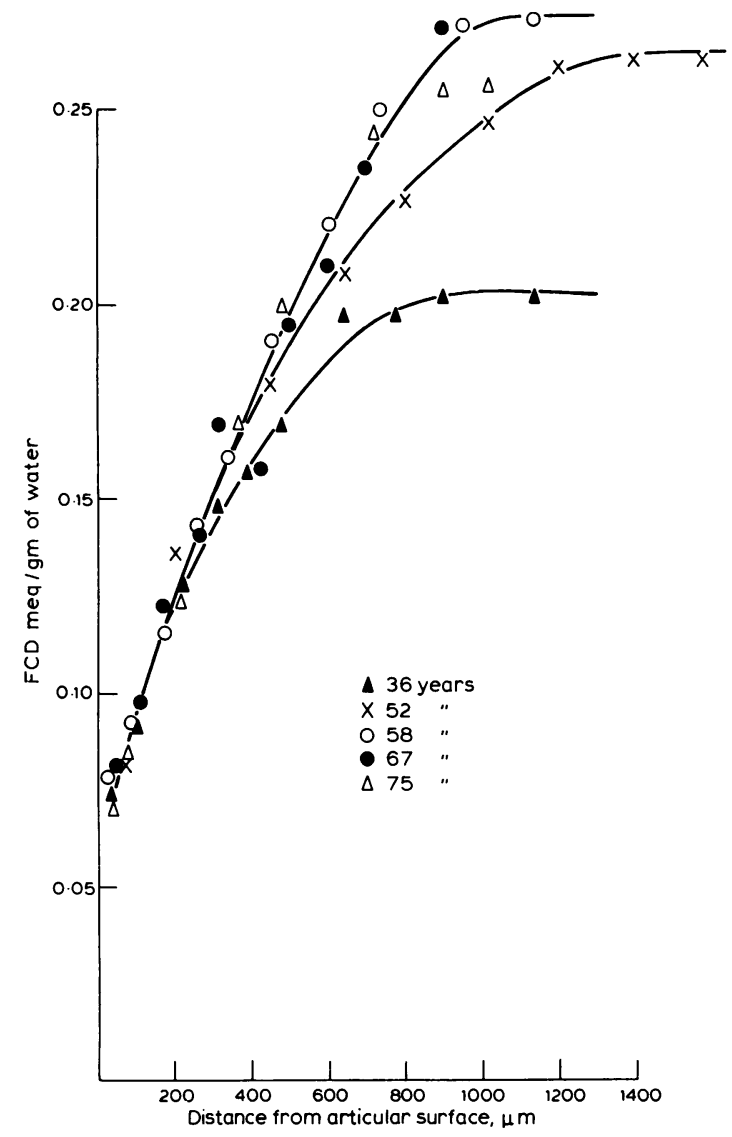

Fig. 1 Typical fixed charge density profiles in the superficial and middle zones of femoral head cartilage. Note that in the deep zone the fixed charge density remains constant. It should be stressed that these are typical profiles. Although specimens from 6 other individuals had been analysed (ages 30, 32, 48, 65, 68, and 70 years), their FCD profiles are very close to those presented for similar ages, and more points would have made the figure very confusing. calculated in Table 3 were included in the table of overall cartilage composition at different levels (Table 4).

It should be noted, however, that the data relating to protein concentration on the one hand and those giving the overall composition of cartilage slices on the other, although pertaining to the same age group, were in fact not obtained on the same tissue specimens.

The fraction of the tissue not accounted for by the constituents given in Table 4 varies from about $0.5 \%$ in the superficial zone to $3 \%$ in the deep zone (that is, from about 2 to $10 \%$ on a dry basis). As was mentioned earlier, the free electrolyte content amounts to some $0.5 \%$ of the tissue. The remainder thus varies from practically zero at the surface to $2.5 \%$ in the deep zone. Although this does not exactly correspond to the nonproteoglycan protein content given in Table 3 for the different levels (this varies from $1 \%$ at the surface to $2 \%$ in the deep zone), the difference is within the range of experimental errors, particularly those pertaining to the collagen determinations.

\section{FIXED CHARGE DENSITY PROFILES}

\section{AND OSMOTIC PRESSURE GRADIENTS}

As Fig. 1 shows, within the first $300 \mu \mathrm{m}$ of the articular surface the fixed charge density profile (based on the water content of the tissue) is the same for all specimens examined. Within the middle zone the slope increased slightly from the 36-year-old to the over-58 age group.

A constant fixed charge density is reached at distances between $800-1000 \mu \mathrm{m}$ from the surface.

Knowing, on the one hand, the variation of the osmotic pressure with fixed charge density for extracted hip proteoglycans ${ }^{10}$ and on the other the shape of the fixed charge density profiles, we are now in a position to calculate the osmotic pressure of the proteoglycans as a function of the distance from the articular surface.

Fig. 2 shows that the osmotic pressure rises linearly with distance from the surface over the first $300-400 \mu \mathrm{m}$; thereafter the slope increases somewhat less in the over-58 year old specimens, but remains practically constant in those from the younger individuals. The most important point to notice is the gradual rise in osmotic pressure in all of the specimens, due to the gradual rise in fixed charge density with depth. Fig. 3 illustrates the effect of this gradual increase in FCD on the magnitude of the osmotic pressure gradient and contrasts it with the gradient which would be present near the surface if the GAG content rose to its maximum value within the first $100 \mu \mathrm{m}$ of the surface. 


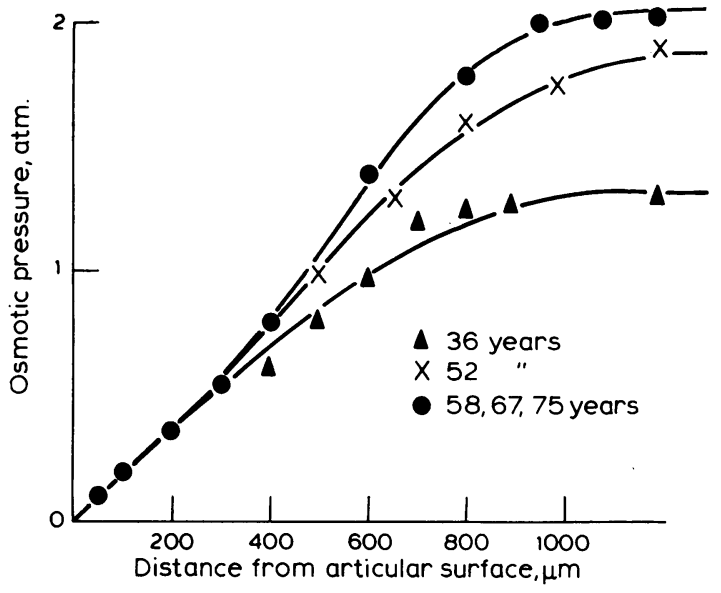

Fig. 2 Osmotic pressure within cartilage as a function of distance from the articular surface. Note that only one single curve is shown for the specimens obtained from the 58,67, and 75 year old individuals. This is because all 3 fixed charge density profiles coincided.

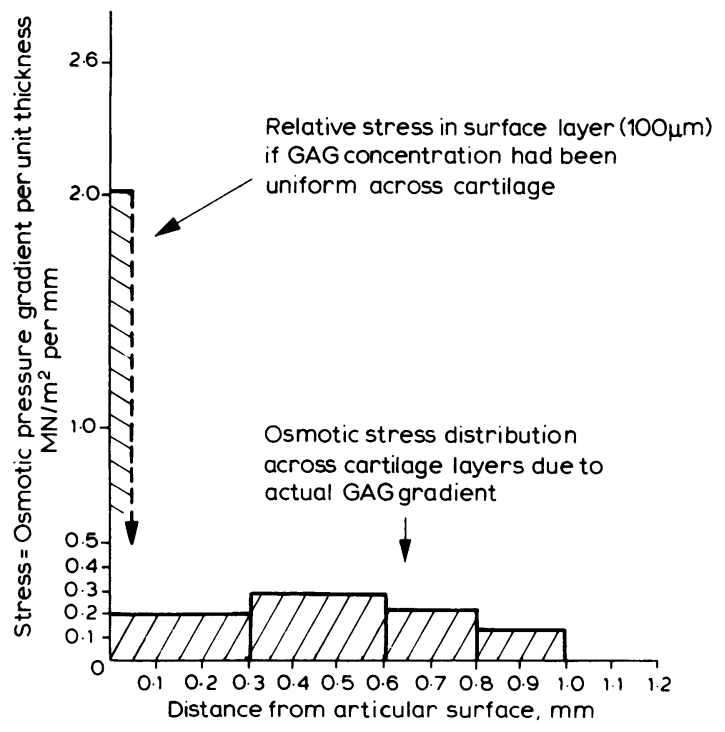

ILLUSTRATION OF GRADED STRESS IN ARTICULAR CARTILAGE

Fig. 3 Osmotic pressure gradients in cartilage.

WET TISS UE VOLUME OF NORMAL

AND OSTEOARTHRITIC CARTILAGE

The wet volume of full depth normal cartilage was calculated per unit weight of collagen and the mean values for each age group are plotted in Fig. 4. The mean fixed charge density values are plotted in the same figure. For comparison we have included a

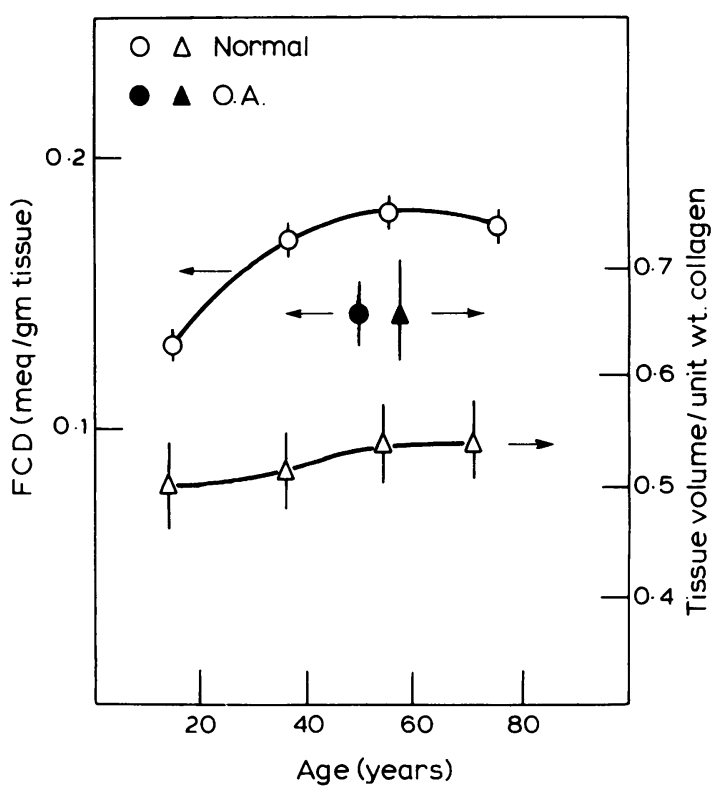

Fig. 4 The variation of $F C D(\phi)$ and $V(\Delta)$ with age for normal femoral head cartilage. Mean value for osteoarthritic cartilage ( $\phi$ for FCD and $\$$ for V) are included for comparison.

mean value of wet volume and FCD for osteoarthritic cartilage, calculated from previously published data on the composition of osteoarthritic tissue. ${ }^{2}$

For normal cartilage there seems to be a very slight increase in 'wet volume' with age, which is consistent with a slight increase in the osmotic gradient (see Fig. 2). It is clear that the 'wet volume' of osteoarthritic cartilage is much higher than that of the normal tissue, though the FCD of the latter is higher.

\section{Discussion}

\section{CARTILAGE COMPOSITION}

It has recently become apparent ${ }^{5}$ that the proteoglycans from adult human articular cartilage contain much more protein than proteoglycans of other origins. The high protein content of adult femoral head cartilage proteoglycans is clearly seen in Table 2: in the over-40 age group the protein constitutes some $40 \%$ of the proteoglycan moiety and some $4 \frac{1}{2} \%$ of the wet weight (or $15 \%$ of the dry weight) of the tissue. If this protein is taken into consideration when the composition of cartilage is being examined it becomes clear that at least $90 \%$ of the dry mass of cartilage can be satisfactorily accounted for in terms of collagen, proteoglycans, and electrolyte (or $97 \%$ of the wet mass of the tissue). 
The 'missing fraction' which used to puzzle some of us in the past ${ }^{124}$ has thus been considerably reduced, and one can be confident now that when one is discussing the functional properties of articular cartilage in terms of the contributions made by collagen and the proteoglycans one is not omitting an unidentified major tissue component.

The high ratio of protein to GAG within the cartilage proteoglycans clearly has important implications with regard to the structure of the latter, but this has been discussed elsewhere ${ }^{5}$ (and Bayliss, Venn, and Maroudas, in preparation).

The high protein content also appears to have an effect on the osmotic pressure of the proteoglycans. Thus, recent measurements have shown ${ }^{10}$ that at equivalent GAG concentrations the ionic contribution to the osmotic pressure for proteoglycans from human articular cartilage is greater than for proteoglycans which contain relatively little protein, such as those derived from bovine cartilage. This has been partly attributed by the authors to the protein excluding the glycosaminoglycans from part of the volume which would otherwise have been available to them.

\section{'WET VOLUME' OF CARTILAGE AND SWELLING PRESSURE GRADIENTS}

Although it has been realised for some time now that in cartilage there is a balance between the swelling pressure of the proteoglycans and the tensile stresses in the tissue, ${ }^{622} 23$ it is only recently that the details have begun to be worked out more clearly. The picture which emerges at present is as follows.

The swelling pressure within cartilage is due primarily to the ionic contribution of the negatively charged groups within the proteoglycan moiety. ${ }^{710}$ However, in contrast to ordinary ion-exchange resins which are internally cross linked, this swelling tendency in cartilage is not balanced by intramolecular cross-links between the proteoglycan molecules themselves, since it is well known that proteoglycans on their own can swell almost indefinitely. Nor are specific interactions between the proteoglycans and the collagen-if any such existjikely to be of importance in opposing the swelling tendency of the PG, since, even if a high proportion of the PG are lost, there is no change in the overall volume of cartilage ${ }^{9}$ (and Maroudas, unpublished results). Hence it is the collagen network alone which is responsible for limiting, in normal cartilage, the swelling of the PG. The tensile stresses in the collagen network are set up not by the overall swelling pressure within the tissue, as was previously implicitly assumed, ${ }^{62}$ but by the swelling pressure differentials arising from the existence of fixed charge density gradients within cartilage. ${ }^{7-9}$
Thus in our view the significant parameters to study in relation to the balance of forces within the unloaded cartilage matrix are on one hand the osmotic pressure gradients within the tissueas they are responsible for the swelling tendencyand on the other hand the overall wet volume of the tissue subtended by a given weight (or volume) of collagen, this 'wet' volume of tissue per unit 'dry' weight of collagen being a measure of the ability of the collagen network to expand.

It should be noted in relation to the latter factor that in previous studies it was either the total water content of the tissue ${ }^{2}$ or the ratio of wet to dry volume of tissue ${ }^{2}{ }^{4}$ which was quoted as a measure of the swelling capacity of the tissue. In fact the use of either of these 2 formulae is somewhat misleading; the former, because for obvious reasons the water content alone does not represent the overall volume occupied by the tissue; the latter, because it is based on the total dry volume of the tissue, whereas it is only the collagen which is the tension-resisting element in cartilage, the proteoglycans and other proteins being inert in this respect.

Examination of Table 2 shows that, while the water content of normal cartilage decreases with age, the wet volume of the tissue per unit weight of collagen varies little, tending if anything to a slight increase. Equally, if one examines the swelling pressure curves for cartilage specimens from individuals of different ages (Fig. 2), one sees relatively little variation in the gradients, though the maximum level of the swelling pressure definitely increases from the 36-year-old to the over-60 age group.

One may thus conclude that in normal adult articular cartilage both the differences in swelling gradients due to the fixed charge density profiles and the stiffness of the collagen network remain nearly constant. On the other hand, in osteoarthritic cartilage, while the fixed charge density is reduced (Fig. 4) the volume of the tissue per unit weight of collagen is substantially increased (Fig. 4). This implies a considerably more extensible (i.e., presumably weakened) collagen network in the osteoarthritic cartilage, which is in accordance with our earlier conclusions. ${ }^{89}$

So far as the variation in the wet volume of the tissue with depth from the articular surface is concerned there is in normal cartilage an increase in the middle zone compared with both the surface and the deep zones. Although this is illustrated only for the 40-60 years age group in this paper, we found the above pattern of variation to be characteristic of adult tissue in other age groups as well. The middle zone does have, particularly in older individuals, a slightly higher swelling pressure gradient than the superficial zone, and this may be partly 
responsible for the larger volume of the tissue per unit weight of collagen in this zone. However, it is also likely that the stronger orientation of the collagen fibres in the superficial and the deep zones as compared with the middle zone ${ }^{25}$ is responsible for the greater stiffness of the collagen network in these zones and hence also for the smaller wet volume of the tissue per unit weight of collagen.

The gentle grading of osmotic stresses in the cartilage, resulting from the fixed charge density profile is illustrated in Fig. 3. This also shows, for comparison, how very much higher the stresses on the collagen network would be if the maximum level of GAG concentrations were reached near the surface. However, this grading of stresses would appear to be designed more as a protection against long-term fatigue than against sudden damage, since collagen fibres in normal cartilage do not disrupt instantaneously or show any measureable swelling even when the osmotic stress is considerably increased, for example, when a slice of high FCD, from the middle zone of femoral head cartilage, is excised and directly exposed to an isotonic (or even a hypotonic solution..$^{8}$

It is of interest to compare this behaviour with that of osteoarthritic cartilage, where the hydration and the wet volume of the tissue increase dramatically in the middle zones (even without excision and osmotic shock), more so than either in the superficial or in the deep zones. ${ }^{89}$ This we attributed to 2 factors: firstly, the damage to the collagen network, which is a prerequisite for any swelling to take place at all, and, secondly, to the development of a steeper osmotic gradient in the middle zone, due to the early loss of the proteoglycans from the surface. (That such early, localised loss occurs has been shown in the past (e.g., Fig. 7 in Maroudas and $V^{2} n^{9}$ ). It can readily be seen, by reference to figs. 1 and 2 that once the level of proteoglycans in the surface zone is decreased the osmotic pressure gradient between the middle zone and the superficial zone will obviously increase considerably. We infer that, if the collagen network has already been somewhat weakened, this increased gradient will cause an even greater swelling in the middle zoneover and above that due to the weakening of the collagen alone. But even if the collagen network in this zone is still intact, the increased osmotic stress on this collagen network of the middle zone is liable to cause fatigue and thus is likely to lead to future damage, followed by swelling-hence leakage of PG-and eventually further disruption.

In more general terms, if any defects in the cartilage surface occur (e.g., clefts), which bring into direct contact with synovial fluid those parts of cartilage which are high in fixed charge density, the collagen network will become locally exposed to considerably increased stresses and will therefore become more prone to failure.

The authors thank the Medical Research Council and the Peter Flemming Charitable Trust for financial support.

\section{References}

1 Maroudas A, Muir $\mathrm{H}$, Wingham $\mathrm{J}$. The correlation of fixed negative charge with glycosaminoglycan content of human articular cartilage. Biochim Biophys Acta 1969; 177: 492-500.

2 Venn M F, Maroudas A. Chemical composition and swelling of normal and osteoarthrotic femoral head cartilage. I: Chemical composition. Ann Rheum Dis 1977; 36: 121-9.

3 Byers P D, Maroudas A, Oztop F, Stockwell R A, Venn ơ M F. Histological and biochemical studies on cartilage $G$ from osteoarthrotic femoral heads with special reference $\vec{A}$ to surface characteristics. Connect Tissue Res 1977; 5: 음 41-9.

4 Venn M F. Variation of chemical composition with age in human femoral head cartilage. Ann Rheum Dis 1978; 37: 168-74.

5 Bayliss M, Ali Y. Age-related changes in the composition and structure of human articular cartilage proteoglycans. Biochem J 1978; 176: 683-93.

6 Maroudas A, Evans H, Almeida L. Cartilage of thê hip joint: topographical variation of glycosaminoglycae content in normal and fibrillated tissue. Ann Rheum $D$ 1978; 32: 1-9.

7 Maroudas A. Physico-chemical properties of cartilagè. In: Freeman M A R, ed. Adult Articular Cartilage. 2nd ed. London: Pitmans, 1979.

8 Maroudas A. Swelling pressure versus collagen tension $\mathbb{Q}$ in normal and degenerate articular cartilage. Nature $\vec{\overrightarrow{ }}$ 1976; 260: 808-9.

- Maroudas A, Venn M F. Chemical composition and swelling of normal and osteoarthrotic femoral head cartilage. II. Swelling. Ann Rheum Dis 1977; 36: 399-406.

10 Urban J P G, Maroudas A, Bayliss M, Dillon J. Swelling pressures of proteoglycans at concentrations found in cartilaginous tissues. Biorheology 1979; in press.

11 Hjertquist S O, Lemperg R C. Studies on autologous diced costal cartilage transplants. III with special regard to glycosaminoglycans, hydroxyproline, calcium and of ${ }^{35} \mathrm{~S}$ sulphate incorporation in vitro after intramuscular 3 implantation. Acta Soc Med Upsal 1967; 72: 173-83.

12 Von Berlepsch K. Two automated procedures for deter- 을 mination of uronic acid in acid glycocaminoglycans. Anal Biochem 1969; 27: 424-9.

13 Bitter T, Muir H. A modified uronic acid carbozole reaction. Anal Biochem 1962; 4: 330-4.

14 Elson L A, Morgan W T J. A colorimetric method for determination of glucosamine and chondrosamine. Biochem J 1933; 27 : 1824-8.

15 Stegemann H. Microbestimmung von Hydroxyprolin $O$ mit chloramin-T und p-Dimethylaminobenzaldehyd. $Z$ Physiol Chem 1958; 311: 41-5.

16 Grant R A. Estimation of hydroxyproline by Auto- $\mathbb{D}$ Analyzer. J Clin Pathol 1964; 17: 685-9.

17 Maroudas A, Thomas H. A simple physicochemical 7 micromethod for determining fixed anionic groups in $\bar{O}$ connective tissue. Biochim Biophys Acta 1970; 215: 214-8.

18 Sweet M B E, Thonar E J-M A, Immelman A R, Solomon L. Biochemical changes in progressive osteoarthritis. $\stackrel{\mathbb{D}}{\square}$ Ann Rheum Dis 1977; 36: 387-98. 
19 Wells J D. PhD Thesis. Australian National University, 1972.

20 Noda H. Partial specific volume of collagen. $J$ Biochem (Tokyo) 1972; 71: 699-703.

21 Meyer F A, Comper W D, Preston B N. Model connective tissue systems. A physical study of gelatin gels containing proteoglycans. Biopolymers $1971 ; 10$ : 1351-64.

22 Fessler J H. A structural function of mucopolysaccharide in connective tissue. Biochem J. 1960; 76: 124-32.
23 Ogston A G. The biological functions of the glycosaminoglycans. Chemistry and Molecular Biology of the Intracellular Matrix. London: Academic Press, $1970 ; 3$.

24 Lipschitz H, Etheredge R, Glimcher M J. Changes in the hexosamine content and swelling ratio of articular cartilage as functions of depth from the surface. $J$ Bone Joint Surg 1976; 58A: 1149-53.

25 McCall J G. Load deformation studies of articular cartilage. J Anat 1969; 105 : 212-4. 